\title{
INTERNATIONAL
}

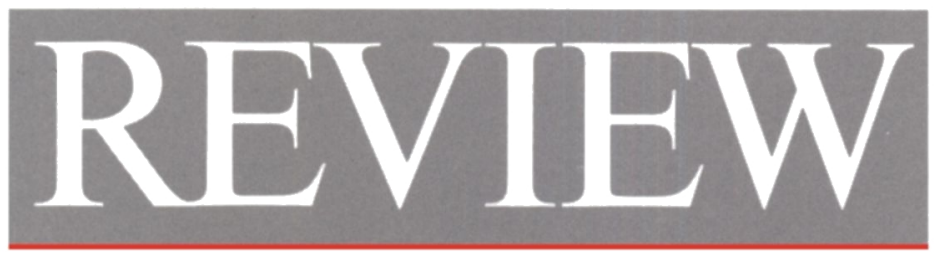

\section{OF THE RED CROSS}

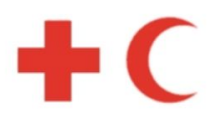

Published every two months by the International Committee of the Red Cross for the International Red Cross and Red Crescent Movement 


\section{INTERNATIONAL COMMITTEE OF THE RED CROSS}

Mr. CORNELIO SOMMARUGA, Doctor of Laws of the University of Zurich, Doctor h.c. rer. pol. of Fribourg University (Switzerland), Doctor h.c. in International Relations of Minho University, Braga (Portugal), Doctor h.c. of Medicine of Bologna University (Italy), Doctor h.c. of NiceSophia Antipolis University, Doctor h.c. of Seoul National University (Republic of Korea), President (member since 1986)

Mr. PIERRE KELLER, Doctor of Philosophy in International Relations (Yale), banker, VicePresident (1984)

Mr. ERIC ROETHLISBERGER, Doctorate of Political Science from the Graduate Institute of International Studies in Geneva, Vice-President (1995)

Mr. ULRICH GAUDENZ MIDDENDORP, Doctor of Medicine, lecturer at the Faculty of Medicine of Zurich University, former head of the surgical department of the Cantonal Hospital, Winterthur (1973)

Mrs. RENÉE GUISAN, General Secretary of the international Institut de la Vie, head of medico-social institutions in the Canton of Vaud, member of the International Association for Volunteer Effort (1986)

Mrs. ANNE PETITPIERRE, Doctor of Laws, Barrister, Professor at the Law Faculty of the University of Geneva (1987)

Mr. PAOLO BERNASCONI, Barrister, LL. L., lecturer in economic criminal law at the Universities of St. Gallen and Zurich, former Public Prosecutor at Lugano, member of the Swiss Pro Juventute Foundation (1987)

Mrs. LISELOTTE KRAUS-GURNY, Doctor of Laws of the University of Zurich (1988)

Mrs. SUSY BRUSCHWEILER, nurse, former Director of the Swiss Red Cross College of Nursing in Aarau, Chairwoman, SV-Service, Contract Catering (1988)

Mr. JACQUES FORSTER, Doctor of Economics, Professor at the Graduate Institute of Development Studies in Geneva (1988)

Mr. JACQUES MOREILLON, Bachelor of Laws, Doctor of Political Science, Secretary General of the World Organization of the Scout Movement, former Director General at the ICRC (1988)

Mr. MAX DAETWYLER, graduate in Economics and Social Sciences of the University of Geneva, Scholar in Residence of the International Management Institute (IMI) of Geneva (1989)

Mr. RODOLPHE DE HALLER, M. D., lecturer at the Faculty of Medicine of the University of Geneva, President of the Swiss Association Against Tuberculosis and Lung Diseases (1991)

Mr. DANIEL THURER, LL. D., LL. M. (Cambridge), Professor at the University of Zurich (1991)

Mrs. FRANCESCA POMETTA, Bachelor of Arts, former Swiss Ambassador (1991)

Mr. JEAN-FRANÇOIS AUBERT, LL. D., Professor at the University of Neuchâtel, former member of the Swiss National Council and Council of States (1993)

Mr. JOSEF FELDMANN, Ph.D., tenured professor at the University of St. Gallen, Corps Commander (Rtd.) of the Swiss army (1993)

Mrs. LILIAN UCHTENHAGEN, Doctor of Economics of the University of Basel, former member of the Swiss National Council (1993)

Mr. GEORGES-ANDRÉ CUENDET, Bachelor of Laws of the University of Geneva, graduate of the Institute of Political Studies of the University of Paris, M.A. from Stanford University (USA), member of the Administrative Council of Cologny, Geneva (1993)

Mr. ERNST A. BRUGGER, Doctor in economic geography, general manager of FUNDES, private foundation for sustainable development, consultant for economic development issues, professor at Zurich University (1995)

\section{EXECUTIVE BOARD}

\section{Mr. CORNELIO SOMMARUGA, President}

Mr. ERIC ROETHLISBERGER, permanent Vice-President

Mr. JACQUES FORSTER, member of the ICRC

Mrs. ANNE PETITPIERRE, member of the ICRC

Mr. JEAN DE COURTEN, Director of Operations

Mr. PETER FUCHS, Director General

Mr. YVES SANDOZ, Director for Principles, Law

and Relations with the Movement 


\title{
INTERNATIONAL REVIEW OF THE RED CROSS
}

\section{CONTENTS}

\author{
JANUARY-FEBRUARY 1996 \\ No. 310
}

\author{
Special \\ 26th INTERNATIONAL CONFERENCE \\ OF THE RED CROSS AND RED CRESCENT \\ (Geneva, 3-7 December 1995)
}

Editorial: Some reflections on the 26th International Conference by Yves Sandoz, Director, Principles, Law and Relations with the Movement

26th International Conference of the Red Cross and Red Crescent (Geneva, 3-7 December 1995)

- Opening ceremony (3 December 1995) ......................................... 7

- First plenary meeting (4 December 1995) .................................... 11

HUMANITARIAN CHALLENGES ON THE THRESHOLD OF THE TWENTY-FIRST CENTURY

Statement by Mr Mario Villarroel Lander, President of the International Federation of Red Cross and Red Crescent Societies... 
Keynote address by $\mathrm{Mr}$ Cornelio Sommaruga, President of the International Committee of the Red Cross

- Commission I - War victims and respect for international humanitarian law

- Commission II - Humanitarian values and response to crisis .....

- Second plenary meeting - Election of five members of the Standing Commission (6 December 1995) ........................................................

- Third plenary meeting - Commission reports and adoption of resolutions (7 December 1995)

Council of Delegates (Geneva, 1 and 2 December 1995) .................... 131

Resolutions of the Council of Delegates ............................................ 139

INTERNATIONAL COMMITTEE OF THE RED CROSS

EDITORSHIP OF THE REVIEW - Jacques Meurant retires.......... 152

New editor-in-chief for the Review ................................................... 154

In view of the large amount of copy, the features "Miscellaneous" (including the table showing the status of ratifications of and accessions and successions to the Geneva Conventions and the Additional Protocols as at 31 December 1995) and "Books and Reviews" have been carried forward to the March-April 1996 issue. In that same issue, the Review will publish more of the particularly important documents relating to the 26th International Conference, together with a report on the Xth session of the General Assembly of the International Federation of Red Cross and Red Crescent Societies (Geneva, 27-29 November 1995). 